\title{
Organizational Barriers which are Facing Electronic Government Implementation: The Electronic Government Implementation Framework
}

\author{
SAMAN SALEH ${ }^{1}$, OMAR A. NAKSHABANDI ${ }^{2}$, MOSLEH ZEEBAREE ${ }^{3}$, GORAN YOUSIF ISMAEL $^{4}$, \\ MUSBAH AQEL ${ }^{5}$ \\ ${ }^{1}$ Institute of Graduate Studies and Research, Department of Management Information System, CYPRUS \\ INTERNATIONAL UNIVERSITY, IRAQ, E-mail: 21813094@student.ciu.edu \\ ${ }^{2}$ HAWLER MEDICAL UNIVERSITY, IRAQ, E-mail: omar.nakshabandi@hmu.edu.krd \\ ${ }^{3}$ Institute of Graduate Studies and Research, Department of Management Information System, CYPRUS \\ INTERNATIONAL UNIVERSITY, IRAQ, E-mail: 21807157@student.ciu.edu \\ ${ }^{4}$ Innovation and Knowledge Management Department, NEAR EAST UNIVERSITY, IRAQ, \\ E-mail: 20185771@std.neu.edu.tr \\ ${ }^{5}$ Institute of Graduate Studies and Research, Department of Management Information System, CYPRUS \\ INTERNATIONAL UNIVERSITY, IRAQ, E-mail: magel@ciu.edu.tr
}

\begin{abstract}
Investigating of e-government specified a few organizational barriers to e-government implementation. This paper proposes a framework for examining how organizational barriers affect the application of e-government. Frame creation depends on three main organizational dimensions. First, the organizational main dimensions, which are related to the culture of organization, include (control system, strategic direction, integration and coordination). Second, the organizational main dimensions which are related to the structure of organization include (adaptability, involvement, integration, agreement, reword and incentive system). Third, the organizational main dimensions, which are related to the Information Technology, include (information transfer, Communication, end user focus and employee learning). We initiate those organizational obstacles which are recognized in major electronic government literature linked to the organizational culture effectiveness and dimensions. The conclusion is that the framework is related to understand organizational barriers which prompt the implementation of electronic government. This research is limited to the framework that has been developed based on the lens of e-government literature in the application theory. It is now necessary to test this model in different contexts. This study tries to demonstrate that key which impedes the factors that are associated to the implementation and enhancement of e-government system. There must be more attention to the progress made in e-government projects quickly and accurately. Thus, there is a strong commitment on the part of each government to implement e-government services.
\end{abstract}

Keywords: E-government; Barriers; Implementation; Organisational dimension; Organisational barriers; IT barriers; Cultural barriers.

\section{JEL Classification: J}




\title{
Obstáculos Organizativos a los que se Enfrenta la Implantación del Gobierno Electrónico: El Marco de Implantación del Gobierno Electrónico
}

\author{
SAMAN SALEH ${ }^{1}$, OMAR A. NAKSHABANDI ${ }^{2}$, MOSLEH ZEEBAREE ${ }^{3}$, GORAN YOUSIF ISMAEL ${ }^{4}$, \\ MUSBAH AQEL ${ }^{5}$ \\ ${ }^{1}$ Institute of Graduate Studies and Research, Department of Management Information System, CYPRUS \\ INTERNATIONAL UNIVERSITY, IRAQ, E-mail: 21813094@student.ciu.edu \\ ${ }^{2}$ HAWLER MEDICAL UNIVERSITY, IRAQ, E-mail: omar.nakshabandi@hmu.edu.krd \\ ${ }^{3}$ Institute of Graduate Studies and Research, Department of Management Information System, CYPRUS \\ INTERNATIONAL UNIVERSITY, IRAQ, E-mail: 21807157@student.ciu.edu \\ ${ }^{4}$ Innovation and Knowledge Management Department, NEAR EAST UNIVERSITY, IRAQ, \\ E-mail: 20185771@std.neu.edu.tr \\ ${ }^{5}$ Institute of Graduate Studies and Research, Department of Management Information System, CYPRUS \\ INTERNATIONAL UNIVERSITY, IRAQ, E-mail: magel@ciu.edu.tr
}

\begin{abstract}
RESUMEN
La investigación del gobierno electrónico especificó algunas barreras organizativas para la aplicación del gobierno electrónico. Este documento propone un marco para examinar cómo las barreras organizativas afectan a la aplicación del gobierno electrónico. La creación del marco depende de tres dimensiones organizativas principales. En primer lugar, las principales dimensiones organizativas, que están relacionadas con la cultura de la organización, incluyen (sistema de control, dirección estratégica, integración y coordinación). En segundo lugar, las principales dimensiones organizativas relacionadas con la estructura de la organización incluyen (adaptabilidad, implicación, integración, acuerdo, reformulación y sistema de incentivos). En tercer lugar, las principales dimensiones organizativas, que están relacionadas con la tecnología de la información, incluyen (transferencia de información, comunicación, enfoque en el usuario final y aprendizaje de los empleados). Iniciamos los obstáculos organizativos que se reconocen en la principal literatura sobre gobierno electrónico vinculados a la eficacia y las dimensiones de la cultura organizativa. La conclusión es que el marco está relacionado con la comprensión de los obstáculos organizativos que impulsan la implementación del gobierno electrónico. Esta investigación se limita al marco que se ha desarrollado sobre la base de la lente de la literatura de gobierno electrónico en la teoría de la aplicación. Ahora es necesario probar este modelo en diferentes contextos. Este estudio trata de demostrar que la clave que impide los factores que se asocian a la aplicación y la mejora del sistema de gobierno electrónico. Hay que prestar más atención a los progresos realizados en los proyectos de administración electrónica de forma rápida y precisa. Por lo tanto, existe un fuerte compromiso por parte de cada gobierno para implementar los servicios de gobierno electrónico.
\end{abstract}

Palabras claves: Gobierno electrónico; Barreras; Implantación; Dimensión organizativa; Barreras organizativas; Barreras informáticas; Barreras culturales.

Clasificación JEL: J

Recibido: 05 de mayo de 2021

Aceptado: 12 de junio de 2021 


\section{Introduction}

Information communication technologies are progressively utilizing the interaction networked development between the organization of government and Citizens (Mbugua, 2018). The concept of e-government emerged in the late 1990's after the tremendous revolution in information technology. There are diverse literatures about the e-government definition (Bannister, 2019; De Vries, et al, 2016) defined e-government as the innovation process of public administration aimed to achieve advanced forms of both government and governance over the ICTs' usage. Sun, et al, (2015) argued that e-government is the use of information and communication technology (ICT) between government and citizens intended (Giri, et al, 2018) for providing public values, such as safety, security and prosperity outcomes that are commonly necessity in aim of afford services to businesses, citizens, and other entities (Meijer, 2015). The principles of e-government services are distributed but not limited to a specific location through the availability of the Internet and information technology, which can be accessed anywhere and at any time, to enhance the delivery of public services and to simplify access to e-government (Kumar et al. 2018; Lindgren and Ventra, 2018). The ability to fully transform e-government institutions does not take place without the consent of the citizen for such innovation and services. Provan, et al, (2017) defines e-government as used for roles whose primary purpose is to deliver safety guidance which might effort on exact risks (e.g. process, ergonomics, transportation, industrial hygiene) or establishing a general safety role to coordinate for offering advice and support (e.g. emergency response, culture, security system management, management of contactor). Őnday, (2016) mentioned that a bureaucratic organization is a pyramidal command structure form of management. The way the bureaucratic organization's formality operates is high and very organized. Organizational diagrams for every department generally exist through an organized process in which the decisions are made. A control structure and stringent command always presents. Bureaucracies are intended to be arranged highly efficient and fair.

Abdelkader, (2015) observed that the reliability has been another important factor in the adoption of e-government services which has a positive impact on the desire to use e-government services (Navaezadeh, 2015), and users are more concerned about the reliability of e-government services. In e-government services, reliability is primarily focused on loading Web pages and reducing downtime while browsing the site (Sharma, 2015). Although e-government services are more reliable than traditional government services, they still need to cover the distance before a person can rely solely on e-government services. Due to the poor quality of e-service, several times, government sites do not work, thereby compromising their reliability (Okunola, et al, 2017).

Abdelkader, (2015) also observed that coordination as a driver conquers the hindrance of changing culture of both specialist organization and administration beneficiary. A similar driver (coordination) closes the obstruction of resistance of some legislative (Shannon, 2017) substances with the venture as well as the trouble that occasionally exists between workers in various offices. Through a similar driver (coordination), the goal of building up and incorporating electronic national databases could be achieved (Herrera, 2018), the coordination between various elements in a similar government, makes it less demanding to trade the information and helps quick finish of the required databases (Ericsson \& Lindberg, 2018).

Silva, et al, (2018) defined e-government as the use of data and technological communication to enhance service conveyance, productivity, adequacy and responsibility among government and citizens. Indeed, another expansive definition which joined the previously mentioned two viewpoints and appended another view which is the correspondence point of view was delineated by (Dawes, et al, 2016) e-government is the usage of ICT to upgrade all administration exchanges with every one of partners' classifications (inside government, between government organizations, organizations and subjects). An extremely critical point of view which featured the estimation of the relationship was proposed by (Ruijer, et al, 2016) who guarantee that the key factor that recognizes e-government from conventional government is the creative relationship which rises between e-government and its 
partners. Additionally (Wilkins, 2016) stated that e-government vision is from the point of view of the relationship, because it described e-government as a permanent responsibility pledged by the government to strengthen the relationship between the private sector resident and the general society division through the transfer of improved and financial departments, productivity, smart, knowledge. The e-government plans a smart relationship between government and citizens that citizens may disclose to credit card details or personal information. Elitaria et al. (2017) mentioned that this type of relationship requires citizens' belief that can be one of the key issues for improving e-government. According to the previous definitions of e-government, can also be defined as a platform to effectively promote and implement all government processes while ensuring transparency and accountability to reduce cost and corruption. At the same time, it satisfies citizens and improves the skills of public sector employees to provide high quality of services (authors).

Denison \& Mishra, (1995) model identifies the traits of the culture and linked values with effectiveness, in the wake of choosing the dimensions, which impact execution a large portion of all. It turned out to be clear that, some of them are comparative by their substance mention to flexibility and stability. Organizations, they maintain, for the purpose of creating stability, consistency and vision dimensions are used, and have a key role in achieving effectiveness. Also the vision provides clear directions of meaning in the organization for people; consistency founds standards that assist their conformism. On the other hand, the level of flexibility in the organization allows it to adapt to external factors, through which change in the organization's behavior and knowledge. This capacity supports shared inner beliefs and values that enable people to commit and participate in change. Table (1) below shows the organizational dimensions and factors according to (Nurdin, et al, 2011: $p$ 17).

\begin{tabular}{cl}
\hline Organizational Dimensions & Factors \\
\hline 1. Involvement & Participation \\
& Commitment \\
& Partnership \\
& Responsibility \\
2. Adaptability & Change Management \\
& Transparency \\
& Trust \\
3. Mission & Organizational learning \\
& Vision \\
4. Bureaucracy & Goal \\
& Strategy \\
& Hierarchyistructure \\
& Regulation \\
& Coordination \\
\hline
\end{tabular}

Table (1) Organizational Dimensions and Factors According to (Nurdin, et al, 2011: p 17)

(Ginevičius \& Vaitkūnaite, 2006) argued that model utilizing refuses wide importance having dimensions and attributing smaller ones to more extensive gathering. That can reduce number of dimensions which were diminished from 25 to 12 . Evacuated dimensions don't vanish these qualities of culture and values that are ordered into twelve dimensions (adaptability, transmission of information, cooperation (collaboration), involvement, learning, strategic direction, care about clients, reward and incentive system, control system, communication, agreement, integration and coordination) 
Table 2. Dimensions, presented in instruments of organizational culture measurements

\begin{tabular}{|c|c|c|}
\hline Name of instrument & Dimensions of organizational culture & Notes \\
\hline $\begin{array}{l}\text { Denison Organizational } \\
\text { Culture Survey [20] }\end{array}$ & $\begin{array}{l}\text { 1) involvement: a) empowerment, b) team orientation, c) capability development; } \\
\text { 2) consistency: a) core values, b) agreement, c) coordination and integration; } \\
\text { 3) adaptability: a) creating change, b) customer focus, c) organizational learning; } \\
\text { 4) mission: a) strategic direction and intent, b) goals and objectives, c) vision }\end{array}$ & $\begin{array}{l}\text { Relationship between } \\
\text { dimensions and measures of } \\
\text { effectiveness are examined } \\
\text { empirically }\end{array}$ \\
\hline $\begin{array}{l}\text { An instrument to } \\
\text { measure organizational } \\
\text { culture [5] }\end{array}$ & $\begin{array}{l}\text { 1) conflict resolution, 2) culture management, 3) customer orientation, 4) disposition } \\
\text { towards change, 5) employee participation, 6) goal clarity, 7) human resource } \\
\text { orientation, 8) identification with the organization, 9) locus of authority, } \\
\begin{array}{l}\text { 10) management style, 11) organization focus, 12) organization integration, } \\
\text { 13) performance orientation, 14) reward orientation, 15) task structure }\end{array}\end{array}$ & $\begin{array}{l}\text { Authors picked out } 114 \\
\text { dimensions. This number was } \\
\text { decreased to } 15 \text { after analysis. } \\
\text { Dimensions are linked with } \\
\text { financial performance [23] }\end{array}$ \\
\hline $\begin{array}{l}\text { Perceived Cultural } \\
\text { Compatibility Index [6] }\end{array}$ & $\begin{array}{l}\text { 1) encourages creativity and innovation, 2) cares about health and welfare of } \\
\text { employees, 3) is receptive to new ways of doing things, 4) is an organization people } \\
\text { can identify with, 5) stresses team work among all departments, 6) measures individual } \\
\text { performance in a clear, understandable manner, 7) bases promotion primarily on } \\
\text { performance, 8) gives high responsibilities to managers, 9) acts in responsible manner } \\
\text { towards environment, discrimination, etc., 10) explains reasons for decisions to } \\
\text { subordinates, 11) has managers who give attention to individual's personal problems, } \\
\text { 12) allows individuals to adopt their own approach to job, 13) is always ready to take } \\
\text { risks, 14) tries to improve communication between departments, 15) delegates } \\
\text { decision-making to lowest possible level and other ones }\end{array}$ & $\begin{array}{l}\text { Totally } 23 \text { items. Authors think } \\
\text { that selected dimensions are } \\
\text { linked with performance. } \\
\text { Instrument was created to assess } \\
\text { merged companies }\end{array}$ \\
\hline $\begin{array}{l}\text { Critical success and } \\
\text { failure factors of } \\
\text { organizational culture } \\
\text { change [24] }\end{array}$ & $\begin{array}{l}\text { 1) communication, 2) leadership, 3) employee participation, 4) HRM training and } \\
\text { development, 5) improvements in teamwork, 6) regular feedback, 7) continuous } \\
\text { change, 8) organization structure, 9) empowerment, 10) creativity and other ones }\end{array}$ & $\begin{array}{l}\text { Dimensions are linked with } \\
\text { changes of organizations }\end{array}$ \\
\hline $\begin{array}{l}\text { Organizational Culture } \\
\text { Profile [7] }\end{array}$ & $\begin{array}{l}\text { 1) competitiveness, 2) social responsibility, 3) supportiveness, 4) innovation, } \\
\text { 5) emphasis on rewards, 6) performance orientation, 7) stability }\end{array}$ & $\begin{array}{l}\text { Authors provide an improved } \\
\text { 0'Reilly's, Chatman's and } \\
\text { Caldwell's instrument version. } \\
\text { An empirical evidence about the } \\
\text { link between dimensions and } \\
\text { performance is not given }\end{array}$ \\
\hline
\end{tabular}

They distinguish the model integration between internal and external adaptation. The identification of the organization's interests with the interests of people is the positive refer of the formers. The final part refers to the capability of improving their ability to modify the reaction to the expectations and external conditions. All organizational dimensions can be shown in table (2) according to (Ginevičius \& Vaitkūnaite, 2006).

Table2. Dimensions, Presented in Instruments of Organizational Culture Measurements According to (Ginevičius \& Vaitkūnaite, 2006: p 3).

The contribution of this research is to formulate a conceptual model that can be used as a frame of reference by government institutions seeking to implement e-government systems and improve services. However, it is expected that the framework of this conceptual model in the field of egovernment will contribute by creating a better understanding among the community of researchers and scholars of the concept of e-government, especially with regard to government implementation issues. Moreover, this model will be proposed as a road map for decision-makers (officials in higher authorities and government institutions) to implement and deploy e-government, to achieve proven and reliable results. 


\subsection{Aim of the Study}

The importance of this study lies in the importance of identifying the main organizational barriers that impede the implementation of e-government in order to improve and succeed in the implementation process. This study tries to show the obstacles associated with implementing and strengthening the e-government system and needs more attention to the rapid and accurate progress of e-government projects. Consequently, the study will attempt to present a framework model in which the organizational obstacles are clarified.

By reaching the above goal, a conceptual model will be formulated, which can be used as a frame of reference by government institutions seeking to implement e-government systems and improve the level of services. However, it is hoped that the framework of this conceptual model in the field of e-government will contribute by creating a better understanding among the community of researchers and scholars of the concept of e-government, especially with regard to government implementation issues. Moreover, this model will be proposed as a road map for decision-makers (officials in higher authorities and government institutions) to implement and deploy e-government. In order to reach proven and reliable results, this model will rely on the practically reliable ((Kim \& Lee, 2004: p 283) model.

\subsection{Research Methodology}

This study utilizes a Systematic Literature Review (SLR) approach, as mentioned by (Rashid and Ratten, 2020). Following this approach, (Rashid and Ratten, 2020) they announced that many studies can contribute to developing aspects of research and related questions by providing the basics of verification. The SLR procedure can assist experienced researchers to develop new, interesting and distinctive paths of research by analyzing and accessing a large volume of academic work, as well as an understanding and awareness of the results of previous research and reaching new results by drawing on them (Rashid and Ratten, 2020). This study to formulate a conceptual model that can be used as a frame of reference by government institutions seeking to implement e-government systems and improve services, we have used primary and secondary data.

\section{Literature Review}

In the perspective of government's organization, one portion of the efficiency of a government's enactment is the result of the e-government implementation (Gonzalez-Zapata \& Heeks, 2015). Hatsu \& Ngassam, (2015) argued that there are many barriers factors proposed for electronic government, they vary from lacking commitment and participation, constrain of environment lack, lack of skills and knowledge, Lack of understanding and analysis required, lack of organization and policy, lack of resources, lack of infrastructure for good governance and lack of culture of interest.

Fox, et al, (2019) displayed that the barriers from two unique observations. Fisrt, government agencies(services suppliers) have investigated the accompanying barriers infrastructure of IT, absence of awareness, absence of security and protection, absence of trust, absence of comprehensive policy, legitimate and administrative system, deficient talented HR, absence of open private coordinated effort/organizations, absence of preparing and information exchange; absence of E-Government change and protection from change, spending plans and working expenses and absence of clear technique. Abdulkareem, (2015) argued that one of the obstacles to the success of e-government was power outages, infrastructure and digital divide, low level of awareness in ICTs, sabotage and theft in communications, information technology, security and privacy equipment, communications and informatics in order to achieve the objectives. Carter, et al, (2016) argued that the increased transparency of government operations through their interaction with citizens that are using technologies and services helps to reduce corruption in the public sector. There is also a lack of trust between citizens and governments due to the fact that government lacks controlling the system and those create major problems for impacting the application of e-government. 
Díaz, et al, (2015) noted that addressing weak capacity and weak knowledge experience in egovernment as well as addressing contextual issues and implementing e-government will facilitate understanding of implementation and the challenges and factors that lead to the success of egovernment. As well as Sorn-In, et al, (2015) pointed out that there are five factors that affect the development of e-government through the use of a citizen-centric approach from the point of view of citizens and government agencies: services that increase the quality of e-government and infrastructure related to informatics, society, economy, governance, politics and organization. Concentrating on the exchange of development in the institution is another obstacle to the process which is not to update the skills, knowledge and capabilities of public sector information workers to support the e-government process.

Sharma, (2015) explained that one of the main factors that influences the use of e-government specifically efficiency, reliability, responsiveness and safety, which are considered as a good service, as well as two other demographic variables: the educational level of citizens and the time in the use of e-government services. Understanding of obstacles to the implementation of e-government and environmental action are one of the most important obstacles for governments in developing countries to turn to "smart governments". There are still many puzzling academics, information practitioners and contemporary e-government governments. This idea was proved by (Schul \& Klichowski, 2007: p890) who argued that "the former or complex nature of understanding these constraints and challenges of integration and interoperability is not well understood", therefore a full understanding organizational, standard, cognitive and cultural issues is critical to address those obstacles that hinder governments from achieving the goals of integration, information exchange and interoperability.

Manda \& Backhouse, (2016) stated that a full understanding of organizational, standard, cognitive and cultural issue are critical to address those obstacles that hinder governments from achieving the goals of integration, information exchange and interoperability. The factors that impede the integration of e-government, interoperability, exchange of information, etc. The study found that the lack of interest in human, social, economic and other factors and the absence of studies in the fields of public administration and political science, the understanding of information systems, information science and sociology (Schedler et al., 2019) effectively different aspects of egovernment (Wilkins, 2016) integration of e-government and joint action. This calls for multidisciplinary studies involving various disciplines that can be taken to present those barriers. Abdelkader, (2015) points out that main obstacle for implementing successful e-government includes different trends (resources of organization and culture). Al-Shboul, et al, (2014) mentioned that main factors that impelling the use of e-government, mainly efficacy, consistency, awareness and security, which measures a good service, as well as two other important variables: citizen's educational level and the first use of e-government services.

Haider, et al, (2016) argued that there were many barriers to the implementation of egovernment, especially in large electronic developments. The main obstacles are political, technical, economic, legal, social, users, lack of strategy, lack of information transfer and other perspectives.

Waller \& Genius, (2015) pointed out that depending on the data examined; the factors challenge the use of information communication technology improves government efficiency, success and communal service delivery. In Jamaica, organizational issues such as high-level management support, the struggle for change to electronic means, lack of cooperation, lack of control system, lack of training courses and lack of qualified staff were the obstacles that identified in Jamaica's egovernment.

Madire, (2015) argued that one of the factors impeding the effective implementation of the egovernment program in the Guerrero city council is the lack of a strategic plan to implement egovernment in the Guerrero city council. The lack of ICT specialists, the inadequacy of information technology equipment and the lack of training for e-government workers are social, not technological and cultural, such as education and age. 
Al-Shboul, et al, (2014) claimed that Awareness of the use of electronic devices on the Internet, and the voice of older generations and the uneducated population in contradiction with the egovernment program. These were the other factors impeding the effective implementation of egovernment in the Gweru City Council.

Kumar, et al, (2018) argued that the most important factors are: ease of use of resources, computer self-efficacy, multilingual choice, compatibility, spitting, trust, and availability of service, trustworthiness, quality of information, threat, reception, reliability, social impact and civic thinking. Citizens to implement the use of e-government services in India. In addition, avoiding corruption, transparency, integrity in the process, consumer support and forced and compulsory adoption are important new reasons.

Alenezi, et al, (2017) argued that barriers which are facing improving organizational performance are lack of information quality, absence completeness and accuracy, lack of objectivity, lack of interpretability, relevancy absence of useful information, low timeliness, security for dependable information, low information believability, and lack of information accessibility (information transmission).

Al-Sai \& Abualigah, (2017) stated that massive measure of accessible information presents experience issues at the first hand and examine in the organization is one of the main challenges that confronted those administrations is the use of the huge information. By the way, the administrations need to make viable arrangement and techniques before taking activities to manufacture a major information investigation. They should also guarantee that the venture of the tasks is worth (benefit) to the country that produces more hindrances, such as lack of communication, lack of information transmission and citizen agreement.

Provan, et al, (2017) pointed out that the lack of individual learning, the lack of legal regulations, the weak structure of the Organization and the lack of relations between managers were all major obstacles to improve the work of governmental organizations.

Kumaraswamy \& Quamar (2018) stated that although the general leaders were willing and committing to adopt the ICT measures to improve the information technology sector and to establish an e-government, there were still some obstacles that were difficult to overcome. Lack of coordination and cooperation between government institutions and the absence of a general strategic such as ICT policy have led to the development of ICT in Bangladesh. The high cost of Internet access, which affected the citizen's desire, weak information transmission, weak communication, weak participation of citizens, and the ability to adapt to the informatics in Bangladesh compared to the Western urban countries.

\section{Organizational Dimension Concept}

\subsection{Involvement}

Hwang, et al, (2018) mentioned that involvement is a value of organization that helps individuals from an organization to gain an awareness of commitment and responsibility through the organization's activities.

Hatsu \& Ngassam, (2015) pointed out that the e-government project faces political challenges because of the politicians' lack of commitment to radical change. Economically, shareholders support most e-government projects in emerging countries and, as a result, support for the source of support represents the ultimate fate of risk commitments.

Alenezi, et al, (2017) claimed that the difficulty of reaching the participants with senior management responsibilities and culture-related challenges are key factors that are affecting the implementation of e-government transfer.

Information transmission is the process of sending analog or digital data over a communication source to one or more network through using computing or other electronic devices. It allows the communication and transfer of implements in a point-to-direct, point-to-multipoint and multipoint- 
to-multipoint environment. Alenezi, et al, (2017) also, in their study provide a valuable and reliable research model for exploring the engines of information quality and barriers to improving the performance of the organization. This study does not constitute a guarantee for improving government performance. E-government projects are complex, include all political, organizational, cultural, technical and media aspects, and are the only factors that drive e-government projects and their success.

\subsection{Strategic Direction}

Strategic direction includes all actions which are taken to attain the objectives of an organizational strategy. Strategic direction refers to all actions and plans that are necessary to be established to work towards gaining this vision.

Hatsu \& Ngassam, (2015) claimed that any e-government inventions to be successful must address the information communication technology appropriately for a specific purpose. The sustainability initiatives also must center on the infrastructure just as vision and commitment.

Alenezi, et al, (2017) mentioned that strategic benefits contribute to cost saving, time saving, cost efforts, speed, efficiency, mobility and decision-making, and innovation in e-services that increase service quality. In addition, regarding institutional values, perceptions of responsibility for the institution include transparency and accountability for credibility

\subsection{Adaptability}

Adaptability is an essential quality in consistently changing environments. Abroad experience demonstrates adaptability and the capacity to adapt to foreign dialects (Haeffner, et al, 2018).

Adaptability emphasizes on the stresses of the external situation, the impact of standards and convictions that help an association to react to the requirement for change (Arfi, et al, 2018).

\subsection{Transmission of Information}

Alenezi, et al, (2017) claimed that the difficulty of reaching the participants with top management responsibilities and the challenges related to culture are the main factors affecting the implementation of e-government transmission of information.

Information transmission is the process of sending analog or digital data over a communication source to one or more network through using computing or other electronic devices. It allows the communication and transfer of implements in a point-to-direct, point-to-multipoint and multipointto-multipoint environment (Alenezi, et al, 2017).

Haider, et al, (2016) argued that many barriers face the implementation of e-government particularly in mega electronic developments. Most of impediments are political, technical, economic, legal, social, users, lack of strategy, lack of information transmission and other perceptions.

\subsection{Cooperation (collaboration)}

Bayer, (2018) pointed out that cooperation can be defined as the process of gathering a group of people together for the sake of mutual benefits or benefits for the purpose of reaching certain goals instead of going into a discussion. It also aims at reaching personal goals (selfish) based on the exchange of experiences and interdependence.

Abdelkader, (2015) pointed out that most of the interviewees stressed on one of the main problems that oppose the implementation of the e-government project which is the result of the opposition of ministries in their priorities and lack of cooperation between the different areas of government departments that are involved in the project.

Acharya, (2018) argued that government should try to ensure that the e-government system is easy to use and meets the expectations of the future of citizens. Moreover, cooperation between 
many government agencies, the private sector and the public sector is critical to the successful implementation of the e-government program by government agencies.

\subsection{Care about Clients}

Lindgren \& van Veenstra, (2018) pointed out that a full transformative capability of electronic government supported by organizations is probably not going to be realized without considerable citizens' acceptance to participate in such initiatives and services.

Osman, et al, (2019) states that e-government helps to increase citizen participation in decisionmaking that reduces corruption and improves transparency

\subsection{Reward and Incentive System}

In order to inspire and encourage the staff, the leaders or decision-makers of the association need to create a reason that enabling impartial performance measurement system. If staffs suspect their performances are measured based on unfair ruling because of personal favorites, gender, race, etc., they will be disheartened. Individuals will also compare the recompenses they have expected against those with similar efforts, and in contradiction of the inputs they have donated to the firm. If they feel unfairness, they might cease to make extra efforts. Furthermore, an actual award system will progress a firm's business atmosphere by rewarding and demanding staffs fairly, and eliminating occasions for shady performances (Noe, et al, (2016).

\subsection{Control System}

A control system manages advices, leads, or standardizes the behavior of other expedients or systems exhausting control loops (Eissa, et al, 2019).

Waller \& Genius, (2015) pointed out that depending on the data examined, the factors challenge the use of information communication technology improve: government efficiency, success and community service. In Jamaica's organizational issues, such as high-level administrative support, the struggle for change in electronic methods, lack of cooperation, lack of a control system, lack of training courses, and lack of qualified personnel were the obstacles identified in e-Gov in Jamaica.

\subsection{Communication}

Informing or switching over of information by writing, speaking, or using some other means, trust is a key factor in accepting a user-initiated communication system (citizen), moreover; security and privacy are major obstacles using internet for this process. Therefore, the community will not communicate or interact with their personal data without their trust in the means of communication. Trust also affects the intention to use the service and directly influence the behavioral intentions (Abu-Salma, et al, 2017).

Putra, et al, (2018) argued that the e-government faces numerous hindrances for example, the absence of awareness in making telematics decisions, the scarcity of qualified human resources, the lack of telecommunications' infrastructure, are the rates of internet are still luxurious and scarce.

\subsection{Agreement}

The situation in which people have the same opinion, or in which they approve or accept something. Ones exposure to certain technology can affect their adoption or use of that technology. An example is the awareness or exposure of the citizens to the internet which makes it easy or difficult for them to adapt to the e government system (Alam, et al, 2018), e-government system is a system that operates online in which computer gadgets and the internet is required, this means that if the people do not have proper orientation or exposure to how the internet or computer technology works (Limba, et al, 2019),e-government will cause a lot of issues in adapting to the 
technology because e-government system needs both the participation of the people and the government (Kamali, 2018).

Integration and Coordination

Creating a more integrated society is the process of regime change that affects resources to achieve results more professionally and successfully (Smith \& Kettner, 2015). The most integrated organization is a way to meet improved demands while reducing resources, maintaining stability and sustainability through specific programs. Organizational integration is much more than coordination or restructuring. However, it is a profound and thoughtful shift in how people think about their work, their communities and their partners. It is more than just replacing one set of software silos with another. Integration has precedence over results and results, rather than process and activity (WHO, 2015). It involves strengthening human resources and resources, arranging projects, partners and target markets. Certainly, broad government coordination is needed to move from coordination to integration (Easa, 2015).

Di Gregorio, et al, (2017) pointed out that lack of coordination and integration between government organizations and the absence of a nationwide ICT policy which have hindered the anticipated ICT growth in numerous governments.

Marra, (2018) concluded that several of the legislative and policy measures are aimed to government concerns which are compromised by lack state of governance, lack of implementation, lack of government coordination, conflicting of legislation and policy and lack of compliance.

Bwalya \& Mutula, (2016) mentioned that e-government information sharing, integration and interoperability is an intricate matter that practitioners and researchers of e-government are still dealing with in developing countries.

\subsection{Employee Learning}

Baeuo, et al, (2016) points out that the lack of appropriate staff training of programs, lack of quality in the provision of financial resources. The political and regulatory obstacles to electronic use and the obstacles in learning citizens, partnership and cooperation are the main problems for introducing an efficient e-government in many countries.

\section{Barriers to E-government and Implementation}

From the researcher's study and depend on the literature reviews, they noticed that there are many barriers facing e-government during implementation in many countries that are related to the organizational dimensions according to the studies of (Denison \& Mishra's, 1995; Ginevičius \& Vaitkūnaite, 2006 ; Kim \&Lee, 2004; Nurdin, et al, 2011), the organizational dimensions are classified into three main parts, each of them includes another sub factors that's in table number (4), and according to the previous literatures that have included the keywords of this study, we prepare the table number (3) that's a demonstration of all the organizational barriers that are facing egovernment implementation. The desiccation below describes the barriers in briefly.

Hatsu \& Ngassam, 2015; Fox, et al ,2019; Provan, et al, 2017; Kumaraswamy \& Quamar, 2018; Marra, 2018; Baeuo, et al, (2016) argued that the most significant barrier that's facing the implementation of e-government application from several perspectives, organizational culture is the lack of regulation and policy, which include organizational rules and enactment that involve the control system administration. While (Fox, et al, 2019; Madire, 2015; Kumaraswamy \& Quamar, 2018; Baeuo, et al, 2016; Marra, 2018), pointed out that one of the mass barrier that is related to this part which is the lack of organizational strategic plan, that includes the future vision of the organization via long and short term plans. As well as (Kumaraswamy \& Quamar, 2018; Marra, 2018; Fox, et al, 2019), noticed that the lack and nonappearance of government coordination is one of the other obstacles that are facing implementation process in this field. In the other side (Kumar, et al, 2018; Hatsu \& Ngassam, 2015; Abdelkader, 2015), illustrate that the culture objectives as lack of 
corruption avoidance, transparency and fair-mindedness in process, consumer support, that affect directly on the relationship between citizen and government.

However, (Carter, et al, 2016; Waller \& Genius, 2015), noticed that lack of control systems as another barrier which is related to the organizational culture that hinder the e-government implementation.

Also, Lack of understanding and needs analysis, absence of security and protection, weak capacities and experiencing weak knowledge in the fields of e-government are other barriers that mentioned by (Díaz, et al, 2015; Haider, et al, 2016).

Considering the problems that are related to other parts of organizational dimension especially in the field of organizational information technology, which argued by each of (Manda \& Backhouse, 2016; Wilkins, 2016; Schedler, et al, 2019; Haider, et al, 2016; Alenezi, et al, 2017; Fox, et al, 2019; AlSai \& Abualigah, 2017; Kumaraswamy \& Quamar, 2018), that a lack of information transmission is the mass obstacle that faces e-government application implementation process.

While each of, (Hatsu \& Ngassam, 2015; Abdulkareem, 2015; Madire, 2015; Di Gregorio, et al, 2017), noticed that lack of infrastructure that contains hardware, software, platforms, databases, as another regular barriers that are dissipated the e-government application implementation process.

Also, other authors like (Waller \& Genius, 2015; Madire, 2015; Provan, et al, 2017; Baeuo, et al, 2016), pointed out that lack of employee training is one of other problems that weakening the implementation of e-government application process.

On the other side (Sharma, 2015; Al-Shboul, et al, 2014; Kumaraswamy \& Quamar, 2018; Baeuo, et al, 2016; Hatsu \& Ngassam, 2015; Sorn-In, et al,2015; Fox, et al, 2019), from their study, they pointed out that lack of citizens knowledge in e-government application \& weak communication lines, and high internet cost are the main obstacles that are facing end users(citizens), therefore, that's lead them to avoid connectives to fulfill the e-government application implementation process.

While (Kumaraswamy \& Quamar, 2018; Baeuo, et al, 2016), argued that lack of cooperation are the main problems for introducing an efficient e-government application implementation process in many countries.

Absence of e-government application protection system and lack of security and privacy are other barriers that are facing implementation of e-government application process as mentioned by (Fox, et al, 2019; Abdulkareem, 2015).

While the barriers that related to the organizational structure are the last part of our discussions in the field of organizational dimension which each of (Hatsu \& Ngassam, 2015; Waller \& Genius, 2015; Alenezi, et al, 2017; Kumaraswamy \& Quamar, 2018; Manda, \& Backhouse, 2016; Wilkins, 2016; Schedler, et al, 2019; Noe, et al, 2016; Baeuo, et al, 2016), argued that significant barrier which is related to this dimension is lack of participation or involvement and integration to e-governments application.

While in other side, each of (Hatsu \& Ngassam, 2015; Waller \& Genius, 2015; Di Gregorio, et al, 2017; Fox, et al, 2019; Carter, et al,2016; Alenezi, et al, 2017), argued that the lack of adaptability as result of lack constrain of environment, weak structure of the organization and deficiency of trust between citizens and e-government application.

As well as (Fox, et al, 2019; Al-Shboul, et al, 2014; Al-Sai \& Abualigah 2017; Alenezi, et al, 2017), mentioned that lack of awareness of citizens using information technology, which leads to weak agreement on the implementation of e-government.

Last but not the least, each of (Manda \& Backhouse, 2016; Wilkins, 2016; Schedler, et al, 2019; Noe, et al, 2016), argued that the weak government policies that assist the financial profits for egovernment employee led to lack of incentive and rewards system. 
Table 3: Organizational Barriers in Implementation of e-government

\begin{tabular}{|c|c|c|}
\hline $\begin{array}{l}\text { Organizational } \\
\text { Dimension }\end{array}$ & Barriers In E-Government & Barriers In E-Government Sources \\
\hline \multirow{6}{*}{$\begin{array}{l}\text { Organizational -culture } \\
\text { 1-control system } \\
\text { 2-strategic direction } \\
\text { 3-integration and } \\
\text { coordination }\end{array}$} & lack of regulation and policy (6) & $\begin{array}{l}\text { (Hatsu \& Ngassam, 2015; Fox, et al ,2019; } \\
\text { Provan, et al, 2017; Kumaraswamy \& } \\
\text { Quamar, 2018; Marra, 2018; Baeuo, et al, } \\
\text { 2016) }\end{array}$ \\
\hline & lack of organizational strategic plan (5) & $\begin{array}{l}\text { ((Fox, et al, 2019; Madire, 2015; } \\
\text { Kumaraswamy \& Quamar, 2018; Baeuo, et } \\
\text { al, 2016; Marra, 2018) }\end{array}$ \\
\hline & lack and absence of government coordination (3) & $\begin{array}{l}\text { (Kumaraswamy \& Quamar, 2018; Marra, } \\
\text { 2018; Fox, et al, 2019) }\end{array}$ \\
\hline & $\begin{array}{l}\text { lack of corruption avoidance, transparency and } \\
\text { fair-mindedness in process, consumer support (3) }\end{array}$ & $\begin{array}{l}\text { (Kumar, et al, 2018; Hatsu \& Ngassam, } \\
\text { 2015; Abdelkader, 2015) }\end{array}$ \\
\hline & lack of control system (2) & $\begin{array}{l}\text { (Carter, et al, 2016; Waller \& Genius, } \\
\text { 2015) }\end{array}$ \\
\hline & $\begin{array}{l}\text { Lack of understanding and need analysis, absence } \\
\text { of security and protection, weak capacities and } \\
\text { experiencing weak knowledge in the fields of e- } \\
\text { government. }\end{array}$ & (Díaz, et al, 2015; Haider, et al, 2016) \\
\hline \multirow{6}{*}{$\begin{array}{l}\text { Information- } \\
\text { technology } \\
\text { 1-communication } \\
\text { 2- transformation of } \\
\text { information } \\
\text { 3- End user focus } \\
\text { 4- employee learning }\end{array}$} & lack of information transmission (8) & $\begin{array}{l}\text { (Manda \& Backhouse, 2016; Wilkins,2016; } \\
\text { Schedler, et al, 2019; Haider, et al, 2016; } \\
\text { Alenezi, et al, 2017; Fox, et al, 2019; Al-Sai } \\
\text { \& Abualigah, 2017; Kumaraswamy \& } \\
\text { Quamar, 2018) }\end{array}$ \\
\hline & $\begin{array}{l}\text { lack of infrastructure that contains hardware, } \\
\text { software, platforms, data-bases (4) }\end{array}$ & $\begin{array}{l}\text { (Hatsu \& Ngassam, 2015; } \\
\text { Abdulkareem,2015; Madire, 2015; Di } \\
\text { Gregorio, et al 2017) }\end{array}$ \\
\hline & lack of employee training (4) & $\begin{array}{l}\text { (Waller \& Genius, 2015; Madire, 2015; } \\
\text { Provan, et al, 2017; Baeuo, et, al, 2016) }\end{array}$ \\
\hline & $\begin{array}{l}\text { lack of citizens knowledge in e-government \& } \\
\text { weak communication lines, and high internet cost } \\
\text { (7) }\end{array}$ & $\begin{array}{l}\text { Sharma, 2015; Al-Shboul, et al, 2014; } \\
\text { Kumaraswamy \& Quamar, 2018; Baeuo, et } \\
\text { al, 2016; Hatsu \& Ngassam, 2015; Sorn-In, } \\
\text { et al,2015; Fox, et al, (2019) }\end{array}$ \\
\hline & lack of cooperation (2) & $\begin{array}{l}\text { (Kumaraswamy \& Quamar, 2018; Baeuo, } \\
\text { et al, 2016), }\end{array}$ \\
\hline & $\begin{array}{l}\text { Lack of e-government protection, insecurity and } \\
\text { privacy (2) }\end{array}$ & (Fox, et al, 2019; Abdulkareem,2015) \\
\hline \multirow{4}{*}{$\begin{array}{l}\text { Organizational- } \\
\text { structure } \\
\text { 1-adaptability } \\
\text { 2- involvement } \\
\text { 3- integration } \\
\text { 4- agreement } \\
\text { 5- reword and incentive } \\
\text { system }\end{array}$} & $\begin{array}{l}\text { lack of participation or involvement and } \\
\text { integration to e-governments application (9) }\end{array}$ & $\begin{array}{l}\text { (Hatsu \& Ngassam, 2015; Waller \& Genius, } \\
\text { 2015; Alenezi, et al, 2017; Kumaraswamy } \\
\text { \& Quamar, 2018; Manda, \& Backhouse, } \\
\text { 2016; Wilkins, 2016; Schedler, et al, 2019; } \\
\text { Noe, et al, 2016; Baeuo, et al, 2016) }\end{array}$ \\
\hline & $\begin{array}{l}\text { Lack of adaptability as result of lack constrain of } \\
\text { environment, weak structure of the organization } \\
\text { and lack of trust among citizens and the } \\
\text { application of e-government (6) }\end{array}$ & $\begin{array}{l}\text { of (Hatsu \& Ngassam, 2015; Waller \& } \\
\text { Genius, 2015; Di Gregorio, et al, 2017; } \\
\text { Fox, et al, 2019; Carter, et al,2016; } \\
\text { Alenezi, et al, 2017) }\end{array}$ \\
\hline & $\begin{array}{l}\text { Lack of citizen's awareness to use information } \\
\text { technology that's leads to a weak e-government } \\
\text { application agreement (4) }\end{array}$ & $\begin{array}{l}\text { (Fox, et al, 2019; Al-Shboul, et al, 2014; Al- } \\
\text { Sai \& Abualigah 2017; Alenezi, et al, 2017) }\end{array}$ \\
\hline & $\begin{array}{l}\text { weak of government policies that assist the } \\
\text { financial profits for e-government employee lead } \\
\text { to lack of incentive and rewards system (4) }\end{array}$ & $\begin{array}{l}\text { (Manda \& Backhouse, 2016; Wilkins, } \\
\text { 2016; Schedler, et al, 2019; Noe, et al, } \\
\text { 2016) }\end{array}$ \\
\hline
\end{tabular}




\section{Developing the Framework}

Governments crosswise over continents and nations are grasping a government framework which is electronic in nature. Each county whether created or creating, rich or poor are utilizing electronic framework as a way to stream information which is extremely basic and helpful for its citizens at the large. The main consideration which drives the government's initiative in receiving e-government practice is a direct result of the inspiration to enhance the negative picture of the government (Syed, et al, (2018). Citizens often blame the government for either being also moderate, inefficient, or lethargic for the vast majority of present-day needs. Government along these lines needs to grasp innovation and disperse data in the smoothest route to the general population on the loose. It is essentially the utilization of ICT to have a powerful and effective system for streaming data whereby government and its organizations can turn out to be specifically responsible to its own stakeholders (Mattoni, 2018).

In this section, we will investigate the relationship between the three organizational dimensions of barriers recognized in e-government literature studies. Relationships are verified by linking the dimension factors to the obstacles found in e-government literature studies (see Tables 1 and 2). The frame is then developed depending on the model (Kim \& Lee, 2004: p 283) as shown below as in fig (1).

Fig.1. Research Model by (Kim \& Lee, 2004: p 283)

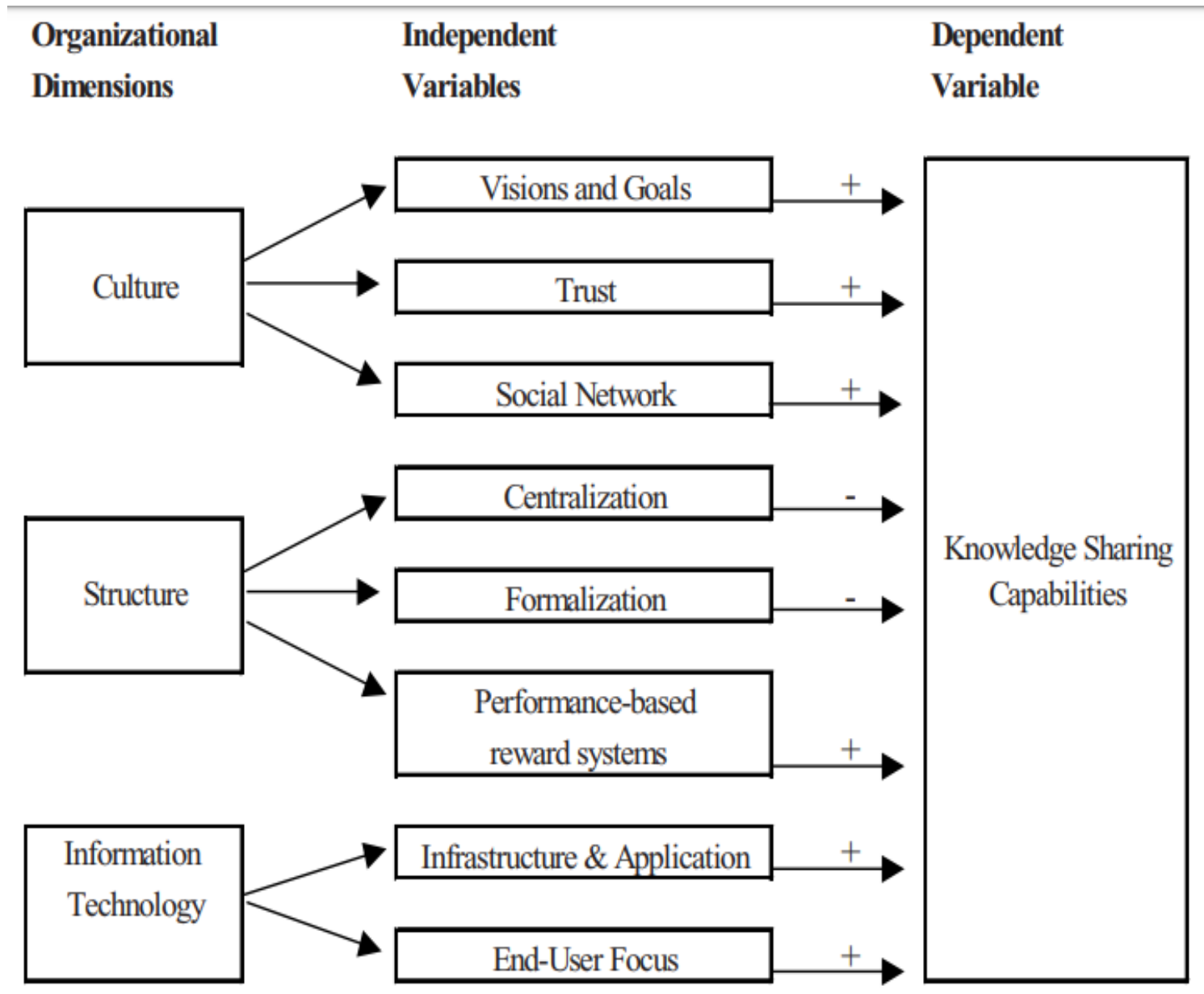

Our methodology and assumption in linking boundaries in e-government implementation (Denison \& Mishra'.1995; Ginevičius \& Vaitkūnaite 2006), measures of organizational culture depend on a hypothesis that works by recognizing the links between characteristics as suggested by the model (Kim \& Lee, 2004), which stipulated that the natural thing can be dictated by the link between 
possessions, either through cooperation or mixing. We have provided evidence that obstacles can be related to the components of the measurements. As a result, each obstacle is suitably placed within reliable measurements to give a noteworthy understanding of how they relate to each other.

For instance, association's versatility is controlled by an association's capacity to make a move as per their ecological desires, for example, nearness of new innovation, new working frameworks, and native's interest. The moves that can be made to manage flexibility may incorporate difference in the board procedure, setting up trust among workers and divisions just as with their partners, and improving straightforwardness. Adjustment inside the new condition likewise requires an association's ability to modify, which can be accomplished through hierarchical and representative learning.

\subsection{The Proposed Framework}

The above dialogue on organizational culture theory and boundaries in the implementation of egovernment was summarized in the accompanying framework as shown in Figure 2, which aims to understand the obstacles in the implementation of e-government in the neighboring government. The structure reflects most of the issues that include obstacles to the use of e-government in government associations. The three main dimensions and issues tend to execute small egovernment. They may influence the adequacy of e-government execution at all government levels.

The relationship between organizational main dimension (according the author classification) and the central government is also envisaged in the framework of work to allow greater insight into external pressures. For example, the first classification is the organizational dimension that is related to the culture of organization, which involves (control system, strategic direction, integration and coordination) The second main dimension is related to organizational structure involves (adaptability, involvement, integration, agreement, reword and incentive system). The third main dimension is related to information technology includes communications, information transfer, end user focus, employee learning) according to table.

Table 4 Organizational Dimension related to Organizational (culture, IT and structure)

\begin{tabular}{cl}
\hline $\begin{array}{c}\text { Organizational classification dimensions } \\
\text { related according }\end{array}$ & \multicolumn{1}{c}{ Related dimension } \\
\hline Organizational Culture & \multicolumn{1}{c}{ Control system } \\
& strategic direction \\
integration and coordination & Converts communications from end-user \\
Information Technology & information to employee learning focus \\
& adaptability \\
Organization structure & involvement \\
& integration \\
& agreement \\
& rewords and incentive system \\
\hline
\end{tabular}

The electronic government implementation framework adapted from (Kim \&Lee, 2004) model as shown in fig (2). 


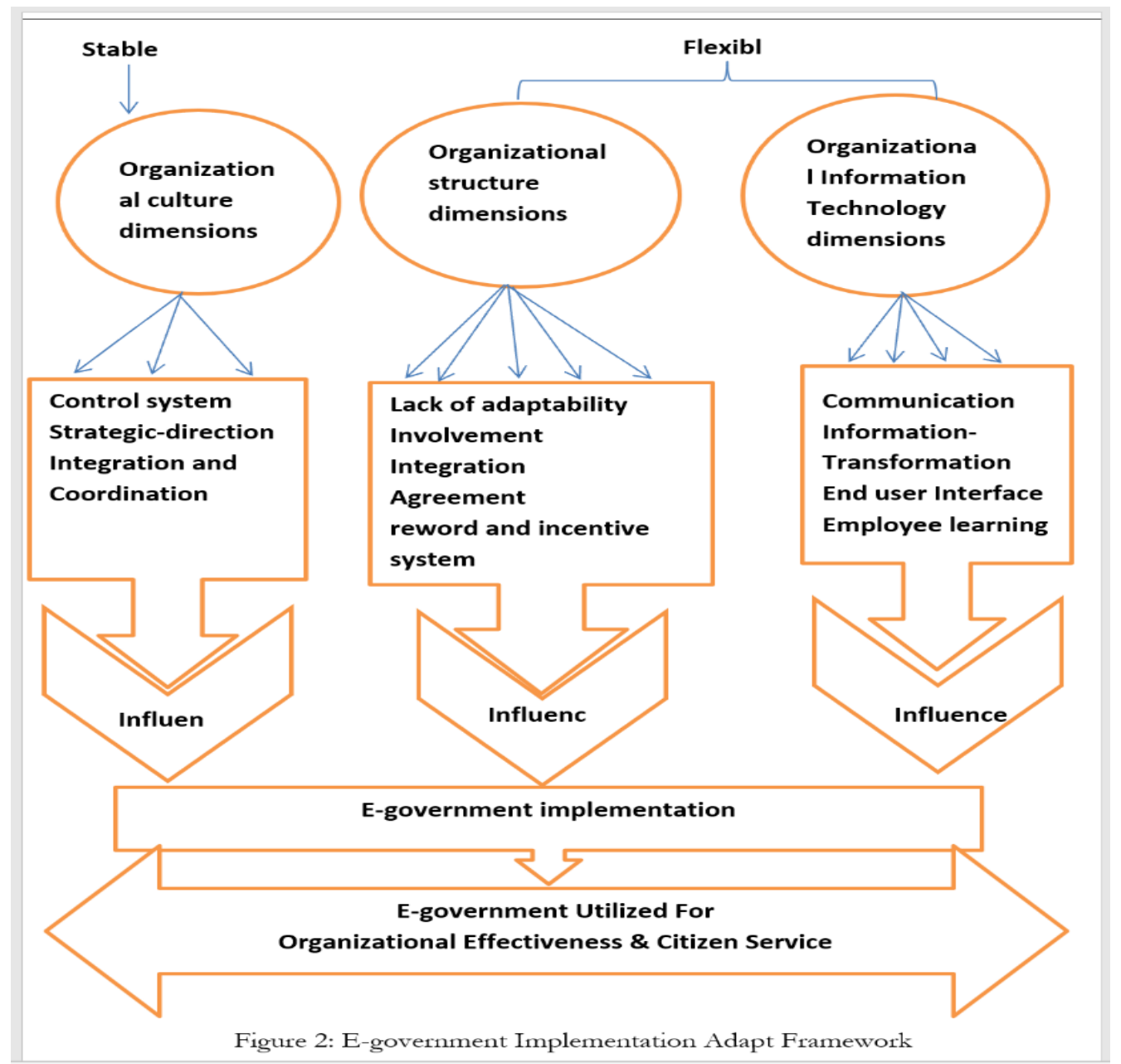

\section{Discussion}

Through the study of researchers and relying on literary reviews, they noticed that there are many obstacles facing e-government during implementation in many countries, which are related to the organizational dimensions according to the specialization of studies, and the organizational dimensions are classified into three main parts. , Each of which includes other sub-factors found in Table No. (4), and according to the previous etiquette that included the key words for this study, we prepare Table No. (3) Which is a presentation of all the organizational barriers facing the implementation of e-government; Several studies have argued that the most important obstacle facing the implementation of e-government implementation from several angles, the organizational culture is the lack of regulation and policy, which includes the regulatory rules and legislation that includes the management of the control system. While others pointed out that one of the public barriers associated with this part is the absence of an organizational strategic plan that includes the future vision of the organization through long- and short-term plans. Some of them also noted that the lack of government coordination and its absence are other obstacles facing the implementation process in this area. On the other hand, many of them make clear that the objectives of the culture are the lack of avoiding corruption, transparency and rationality in the process, and consumer support, which directly affect the relationship between the citizen and the government. However, two of them noted that the lack of monitoring systems is another obstacle related to the regulatory culture that hinders the implementation of e-government. Lack of understanding and analysis of needs, lack of security and protection, weak capacities and the suffering of poor knowledge in areas of e-government are other obstacles. Given the problems related to other parts of the organizational dimension, especially in the field of organizational information technology, which most researchers 
have argued, the lack of information transfer is the collective obstacle facing the implementation of e-government applications. While others pointed out that the lack of infrastructure that includes hardware, software, platforms and databases is considered as other regular obstacles that hinder the implementation of e-government applications.

Meanwhile, other authors pointed out that the lack of employee training is another problem that weakens the implementation process, the lack of knowledge of citizens about e-government implementation, poor communication lines, and the high cost of the Internet are the main obstacles facing end-users (citizens), which leads them to avoid them. Others argued that the lack of cooperation is the main problem for introducing an effective e-government implementation process in many countries, and the absence of an e-government application protection system, insecurity and privacy are other obstacles facing e-government implementation, as we mentioned, while the barriers related to the organizational structure It is the last part of our discussions in the area of the regulatory dimension in which many parties have argued that the major obstacle related to this dimension is the lack of participation and integration in the application of e-government. In addition, some of them agreed that the inability to adapt as a result of the absence of restrictions on the environment, the weakness of the organization's structure, and the lack of confidence among citizens in the application of e-government are other obstacles. And they mentioned that the citizens' lack of awareness of the use of information technology, which also leads to poor agreement on implementing e-government. Last but not least, others have argued that weak government policies that help achieve financial profits for e-government employees and lead to a lack of incentives are problems that must be taken into consideration.

\section{Results}

Depend on the literature review and the paper finding we can say that that huge numbers of authors argued that main barriers that are related to the organizational culture dimension are lack of regulation and policy and lack of organizational strategic plan ,also, many of authors pointed out that the critical obstacle that linked to organizational dimension related to information technology is lack of information transmission, lack of citizens knowledge in e-government \& weak communication lines, and high internet cost, lack of infrastructure that contains hardware, software, platforms, databases, and lack of employee training, while, oversize numbers of authors mentioned that stringent organizational barriers that are facing implementation e-government application that are related to the organizational structure are lack of participation or involvement and integration to egovernments application, lack of adaptability as result of lack constrain of environment, weak structure of the organization and lack of trust among citizens and the application of e-government, lack of citizen's awareness to use information technology that leads to a weak e-government application agreement, weak of government policies that assist the financial profits for e-government employee, lead to lack of incentive and rewards system.

\section{Conclusions}

This paper refers to the relationship between the three dimensions of effective organizational culture and obstacles to the implementation of e-government. This indicates to intend a framework which is built from the three main theories that are related to organizational studies by (Denison \& Mishra, 1995; Ginevičius \& Vaitkūnaite 2006), as organizational culture measurements depend on hypothesis working through recognizing connections between properties as proposed by (Kim \&Lee, 2004) model, for understanding the barriers related to organizational culture which influence egovernment implementation. The suggested framework includes the impact of stable and flexible organizational barriers influencing implementation of e-government for continuing the process that includes many organizational restrictions. A strong framework for understanding the constraints affecting the implementation of e-government is vital and effective. Therefore, the proposed 
framework is presented as a gain to increase understanding of e-government implementation of organizational effectiveness and citizen service.

\section{Recommendations}

A full understanding of the obstacles to the implementation of e-government and environmental action is one of the major obstacles to governments in developing countries "smart governments". There are still many puzzling academics, information practitioners and contemporary e-government governments. This idea was proved by (Schul \& Klichowski, 2007:p 890) who argued that "the former or complex nature of understanding these constraints and challenges of integration and interoperability is not well understood". Therefore, a full understanding of organizational, standard, intellectual and cultural issue is critical to address those hindrances that impede governments from attaining the goals of incorporation, information exchange and interoperability. Through the study of the researcher to the problems that impede the application of e-government on the organizational dimensions based on previous studies on the subject from the point of view of the researcher after analyzing the problems from the point of view of researchers in this area realized the importance of governments to solve the problems related to the implementation of e-government. Therefore, the researcher recommends the need for governments to legislate laws that facilitate the tasks of the egovernment, and to develop strategic plans and clear future vision, and the need to combat corruption and support transparency. As well as improve the process of transfer of information, which, from providing infrastructure such as the Internet, safe communication networks, to providing computers and original software. In addition to, training employees, also, raise the level of knowledge and creating trust between citizen and government through the participation of citizens in the legislation of laws and instructors, as well as improving privacy and security and attention to the governmental structure of the government. The way to adopt bureaucracy in government institutions and increase the awareness of citizens of the importance of information, as well as support of financial policies by motivating employees through bonuses and financial incentives that all contribute, in the future, in improving the implementation of the e-government and participation and acceptance by the citizen and this is what successful governments seek.

\section{References}

1 Abdelkader, A. (2015). A Manifest of Barriers to Successful E-Government: Cases from the Egyptian Programme. International Journal of Business and Social Science, 6(1), 169-186.

2 Abdulkareem, A. K. (2015). Challenges of e-government implementation in the Nigerian public service. JOURNAL OF CREATIVE WRITING | ISSN 2410-6259, 1(04), 45-56.

3 Abu-Salma, R., Sasse, M. A., Bonneau, J., Danilova, A., Naiakshina, A., \& Smith, M. (2017, May). Obstacles to the adoption of secure communication tools. In 2017 IEEE Symposium on Security and Privacy (SP) (pp. 137-153). IEEE.

4 Acharya, B. (2018). Modeling local government's Perception towards implementation of ICT infrastructure and services through Public Private Partnership Mechanism: Case of Nepal).

5 Alam, S. L., \& McLoughlin, C. (2018). E-Citizenship Skills Online: A Case Study of Faculty Use of Web 2.0 Tools to Increase Active Participation and Learning. In Information and Technology Literacy: Concepts, Methodologies, Tools, and Applications (pp. 878-896). IGI Global.

6 Alenezi, H., Tarhini, A., Masa'deh, R. E., Alalwan, A., \& Al-Qirim, N. (2017). Factors Affecting the Adoption of e-Government in Kuwait: A Qualitative Study. Electronic Journal of e-Government, 15(2).

7 Al-Haddad, S., \& Kotnour, T. (2015). Integrating the organizational change literature: a model for successful change. Journal of Organizational Change Management, 28(2), 234-262.

8 Al-Sai, Z. A., \& Abualigah, L. M. (2017, May). Big data and e-government: a review. In 2017 8th International Conference on Information Technology (ICIT) (pp. 580-587). IEEE. 
9 Al-Shboul, M., Rababah, O., Ghnemat, R., \& Al-Saqqa, S. (2014). Challenges and factors affecting the implementation of e-government in Jordan. Journal of Software Engineering and Applications, 7(13), 1111.

10 Arfi, W. B., Hikkerova, L., \& Sahut, J. M. (2018). External knowledge sources, green innovation and performance. Technological Forecasting and Social Change, 129, 210-220.

11 Baeuo, M. O. M., Rahim, N. Z. A., \& Alaraibi, A. A. M. (2016). Technology Aspects of EGovernment Readiness in Developing Countries: A Review of the Literature. Computer and Information Science, 9(4), 1

12 Bannister, F. (2019). From Informatisation to e-Government and Beyond. In Public Administration in Europe (pp. 101-111). Palgrave Macmillan, Cham.

13 Bayer, M. J. (2018). Deliberation in the Lab: The Effect of Communication on Information Sharing, Cooperation, and Consensus.

14 Bryson, J. M., Edwards, L. H., \& Van Slyke, D. M. (2018). Getting strategic about strategic planning research.

15 Bwalya, K. J., \& Mutula, S. (2016). A conceptual framework for e-government development in resource-constrained countries: The case of Zambia. Information Development, 32(4), 11831198.

16 Carter, L., Weerakkody, V., Phillips, B., \& Dwivedi, Y. K. (2016). Citizen adoption of e-government services: Exploring citizen perceptions of online services in the United States and United Kingdom. Information Systems Management, 33(2), 124-140.

17 Dawes, S. S., Vidiasova, L., \& Parkhimovich, O. (2016). Planning and designing open government data programs: An ecosystem approach. Government Information Quarterly, 33(1), 15-27.

18 De Vries, H., Bekkers, V., \& Tummers, L. (2016). Innovation in the public sector: A systematic review and future research agenda. Public administration, 94(1), 146-166.

19 Denison, D. R., \& Mishra, A. K. (1995). Toward a theory of organizational culture and effectiveness. Organization science, 6(2), 204-223.

20 Di Gregorio, M., Nurrochmat, D. R., Paavola, J., Sari, I. M., Fatorelli, L., Pramova, E., ... \& Kusumadewi, S. D. (2017). Climate policy integration in the land use sector: Mitigation, adaptation and sustainable development linkages. Environmental Science \& Policy, 67, 35-43.

21 Díaz, S., Demissew, S., Carabias, J., Joly, C., Lonsdale, M., Ash, N., ... \& Bartuska, A. (2015). The IPBES Conceptual Framework-connecting nature and people. Current Opinion in Environmental Sustainability, 14, 1-16.

22 Easa, S. M. N. (2015). Role of United Nations Development Programme in Supporting Human Development in South Darfur (Doctoral dissertation, Sudan University of Science \& Technology).

23 Eissa, M. M., Ali, A. A., Abdel-Latif, K. M., \& Al-Kady, A. F. (2019). A frequency control technique based on decision tree concept by managing thermostatically controllable loads at smart grids. International Journal of Electrical Power \& Energy Systems, 108, 40-51.

24 Ericsson, E., \& Lindberg, A. (2018). Development opportunities in the land management process in Rwanda: In order to achive a more effective and efficient land use.

25 Fox, M., Service, M., Moore, H., Dean, M., \& Campbell, K. (2019). Barriers and facilitators to shellfish cultivation. Reviews in Aquaculture.

26 Ginevičius, R., \& Vaitkūnaite, V. (2006). Analysis of organizational culture dimensions impacting performance. Journal of business economics and management, 7(4), 201-211.

27 Giri, S., Shakya, S., \& Pande, R. N. (2018). E-Governance Implementation: Challenges of Effective Service Delivery in Civil Service of Nepal. Global Journal of Computer Science and Technology.

28 Gonzalez-Zapata, F., \& Heeks, R. (2015). The multiple meanings of open government data: Understanding different stakeholders and their perspectives. Government Information Quarterly, 32(4), 441-452.

29 Haider, Z., Shuwen, C., \& Burdey, M. B. (2016). E-Government Project Obstacles in Pakistan. International Journal of Computer Theory and Engineering, 8(5), 362. 
30 Hatsu, S., \& Ngassam, E. K. (2015, May). An exploration of critical success factors for eGovernance project initiation: A preliminary framework. In 2015 IST-Africa Conference (pp. 1-8). IEEE.

31 Herrera, M. (2018). Work and Aging: A Review from the Employer's Perspective. In Handbook of Rehabilitation in Older Adults (pp. 299-325). Springer, Cham.

32 Hwang, Y., Lin, H., \& Shin, D. (2018). Knowledge system commitment and knowledge sharing intention: The role of personal information management motivation. International Journal of Information Management, 39, 220-227.

$33 \mathrm{Ju}, \mathrm{Bei}$, and Todd L. Sandel. "Adaptation of Mainland Chinese Labour Migrants in Macao."Journal of Intercultural Communication Research 48.3 (2019): 257-273.

34 Kamali, A. M. A. (2018). An Investigation of e-Government Adoption in Bahrain and Evaluate the key Determining Factors for Strategic Advantage (Doctoral dissertation, London South Bank University).

35 Kim, S., \& Lee, H. (2004, May). Organizational factors affecting knowledge sharing capabilities in e-government: An empirical study. In IFIP international working conference on knowledge management in electronic government (pp. 281-293). Springer, Berlin, Heidelberg.

36 Kumar, R., Sachan, A., Mukherjee, A., \& Kumar, R. (2018). Factors influencing e-government adoption in India: a qualitative approach. Digital Policy, Regulation and Governance, 20(5), 413433.

37 Kumaraswamy, P. R., \& Quamar, M. M. (Eds.). (2018). Contemporary Persian Gulf: Essays in Honour of Gulshan Dietl, Prakash Chandra Jain and Grijesh Pant. Routledge.

38 Limba, T., Agafonov, K., Paukštè, L., Damkus, M., \& Plèta, T. (2019). Peculiarities of cyber security management in the process of internet voting implementation.

39 Lindgren, I., \& van Veenstra, A. F. (2018, May). Digital government transformation: a case illustrating public e-service development as part of public sector transformation. In Proceedings of the 19th Annual International Conference on Digital Government Research: Governance in the Data Age (p. 38). ACM.

40 Madire, D. (2015). An examination into the factors that hinder the effective implementation of egovernment: the case of Gweru city council.

41 Majumdar, A. K. (2015). Fundamentals of free-space optical (FSO) communication system. In Advanced Free Space Optics (FSO) (pp. 1-20). Springer, New York, NY.

42 Manda, M. I., \& Backhouse, J. (2016, July). An analysis of the barriers to e-government integration, interoperability and information sharing in developing countries: A systematic review of literature. In Proceedings of the African Conference in Information Systems and Technology, Accra, Ghana (pp. 5-6).

43 Marra, M. (2018). The ambiguities of performance-based governance reforms in Italy: Reviving the fortunes of evaluation and performance measurement. Evaluation and program planning, 69, 173-182.

44 Mattoni, (2018). From data extraction to data leaking. Data-activism in Italian and Spanish anticorruption campaigns. PARTECIPAZIONE E CONFLITTO, 10(3), 723-746.

45 Mbugua, (2018). Information and communication technologies for knowledge management processes in the public sector in Kenya: a case study of the State Department of Infrastructure (Doctoral dissertation).

46 Meijer, A. (2015). E-governance innovation: Barriers and strategies. Government Information Quarterly, 32(2), 198-206.

47 Navaezadeh, S. (2015). Evaluating reliability and load balance in grid distributed systems. International Journal of Computer Applications Technology and Research, 4(11), 786-788.

48 Noe, R. A., Hollenbeck, J. R., Gerhart, B., \& Wright, P. M. (2016). Fundamental of Human Resource Management (Sixth).

49 Nurdin, N., Stockdale, R., \& Scheepers, H. (2011). Understanding organizational barriers influencing local electronic government adoption and implementation: the electronic 
government implementation framework. Journal of theoretical and applied electronic commerce research, 6(3), 13-27.

50 Okunola, O. M., Rowley, J., \& Johnson, F. (2017). The multi-dimensional digital divide: Perspectives from an e-government portal in Nigeria. Government Information Quarterly, 34(2), 329-339.

51 Őnday, Ő. (2016). Classical Organization Theory: From generic management of Socrates to bureaucracy of Weber. International Journal of Business and Management Review, 4(1), 87-105.

52 Osman, I. H., Anouze, A. L., Irani, Z., Lee, H., Medeni, T. D., \& Weerakkody, V. (2019). A cognitive analytics management framework for the transformation of electronic government services from users' perspective to create sustainable shared values. European Journal of Operational Research.

53 Provan, D. J., Dekker, S. W., \& Rae, A. J. (2017). Bureaucracy, influence and beliefs: A literature review of the factors shaping the role of a safety professional. Safety science, 98, 98-112.

54 Rashid, S., \& Ratten, V. (2020). A Systematic Literature Review on Women Entrepreneurship in Emerging Economies While Reflecting Specifically on SAARC Countries. In Entrepreneurship and Organizational Change (pp. 37-88). Springer, Cham.

55 Ruijer, Erna, et al. "Connecting societal issues, users and data. Scenario-based design of open data platforms."Government Information Quarterly 34.3 (2017): 470-480.

56 Sá, F., Rocha, Á., \& Cota, M. P. (2016). From the quality of traditional services to the quality of local e-Government online services: A literature review. Government Information Quarterly, 33(1), 149-160.

57 Schedler, K., Guenduez, A. A., \& Frischknecht, R. (2019). How smart can government be? Exploring barriers to the adoption of smart government. Information Polity, (Preprint), 1-18.

58 Scholl, H. J., \& Klischewski, R. (2007). E-government integration and interoperability: framing the research agenda. International Journal of Public Administration, 30(8-9), 889-920.

59 Shannon, L. (2017). The Effectiveness of Using Business Ethics in Order to Achieve a Successful Business.

60 Sharma, M. (2018). Understanding Managerial Perception of Corporate Social Responsibility Practices in a Public Sector Undertaking: An Empirical Study (Doctoral dissertation, BITS Pilani).

61 Sharma, S. K. (2015). Adoption of e-government services: The role of service quality dimensions and demographic variables. Transforming Government: People, Process and Policy, 9(2), 207222.

62 Silva, B. N., Khan, M., \& Han, K. (2018). Towards sustainable smart cities: A review of trends, architectures, components, and open challenges in smart cities. Sustainable Cities and Society, 38, 697-713.

63 Sorn-In, K., Tuamsuk, K., \& Chaopanon, W. (2015). Factors affecting the development of egovernment using a citizen-centric approach. Journal of Science \& Technology Policy Management, 6(3), 206-222.

64 Sun, P. L., Ku, C. Y., \& Shih, D. H. (2015). An implementation framework for E-Government 2.0. Telematics and Informatics, 32(3), 504-520.

65 Syed, R., Bandara, W., \& French, E. (2018). Effective leadership in Public Sector BPM: A case study of an e-Government initiative in a developing country.

66 Waller, L., \& Genius, A. (2015). Barriers to transforming government in Jamaica: challenges to implementing initiatives to enhance the efficiency, effectiveness and service delivery of government through ICTs (e-Government). Transforming Government: People, Process and Policy, 9(4), 480-497.

67 Wilkins, D. (2016). A case study investigation of e-Government adoption using an open source software-based web portal in developing countries: The case study of e-Liberia (Doctoral dissertation, Colorado Technical University).

68 Witarsyah, D., Sjafrizal, T., Fudzee, M. D., Farhan, M., \& Salamat, M. A. (2017). The critical factors affecting e-government adoption in Indonesia: A conceptual framework. International Journal on Advanced Science, Engineering and Information Technology, 7(1), 160-167. 
Organizational Barriers which are Facing Electronic Government Implementation: The Electronic Government Implementation Framework

69 World Health Organization. (2015). WHO global strategy on people-centred and integrated health services: interim report (No. WHO/HIS/SDS/2015.6). World Health Organization. 